\title{
ZAPOŻYCZENIA JĘZYKOWE W SYSTEMIE JĘZYKÓW HASEŁ PRZEDMIOTOWYCH
}

\author{
Anna Stanis \\ Biblioteka Uniwersytecka w Warszawie
}

Język haseł przedmiotowych, globalizacja, zapożyczenia językowe, internacjonalizmy, jhp KABA, jhp BN, Słownik hasef przedmiotowych z dziedzin policyjno-prawnych

Koniec XX i początek XXI w. jest czasem wielkich przemian. Zmiany polityczne, ekonomiczne, społeczne spowodowały przemiany kulturowe, pojawienie się nowych zachowań, stylu bycia i idącą za tym zmianę mentalności, odcisnęły też wyraźne piętno na poszczególnych językach. Wśród wielu zmian, jakie zachodzą w tych językach, najbardziej widoczny jest przyrost słownictwa obcego, a szczególnie zapożyczeń angielskich i internacjonalizmów.

Według Encyklopedii Językoznawstwa Ogólnego „zapożyczenie językowe to element przejęty z obcego języka. Najczęściej jest nim wyraz rzadziej prefiks lub sufiks" natomiast „internacjonalizm [to] wyraz albo wyrażenie frazeologiczne występujące (w postaci adaptowanej do ortografii, struktury fonologicznej i gramatycznej danego języka) w wielu językach świata ${ }^{1}$.

Wzmożony napływ zapożyczeń i internacjonalizmów, jaki obserwujemy w ostatnim dwudziestoleciu, jest procesem, który wpływa na system słowotwórczy współczesnego języka polskiego. Wiele z nich jest często używanych w ogólnie dostępnych mediach (telewizji, prasie).

Pierwszym z powodów, który wpłynął na intensywne przejmowanie zapożyczeń do słownictwa dzisiejszej polszczyzny, była chęć jej wzbogacenia (nowe zjawiska - nowe wyrażenia), drugim powodem tak masowej skali pojawiania się elementów obcych jest uleganie modzie językowej. Dotyczy to zarówno anglicyzmów (amerykanizmów), jak i wyrazów pochodzących z innych języków: z francuskiego, np. balejaż, z włoskiego np. paparazzi, z hiszpańskiego np. macho, z japońskiego np. jacuzzi, sushi, z arabskiego np. dżihad.

\section{Dominacja języka angielskiego}

Dziś status angielszczyzny jest dominujący: korzysta z niej trzecia część ludności świata, mimo że jest macierzystym językiem dla $380 \mathrm{mln}$ ludzi, dominuje w sferze książek, czasopism, filmów; ok. $80 \%$ treści zamieszczanych w Internecie ma angielską formę językową, chociaż 44\% użytkowników Internetu mówi innymi językami. Angielski jest używany przede wszystkim przez elity techniczne, gospo-

\footnotetext{
${ }^{1}$ Encyklopedia językoznawstwa ogólnego. Wroclaw, Warszawa, Kraków 1993.
} 
darcze i polityczne ${ }^{2}$. Język ten rozpowszechniony jest tak bardzo, że został nazwany „łaciną Internetu” („Łacina Internetu” - uniwersalny kod, przez który rozumie się język angielski) ${ }^{3}$.

Piotr Wróblewski przeprowadził anonimową ankietę w środowisku młodego pokolenia Polaków na temat zmian zachodzących we wspólczesnej polszczyźnie, badaniom poddano 100 osób, studentów I roku polonistyki Uniwersytetu w Białymstoku oraz słuchaczy II i III roku Kolegium Nauczycielskiego w Suwałkach. W odpowiedzi na pytanie dotyczące zmian zachodzących w języku 98\% ankietowanych odpowiedziało, że zauważa zmiany we współczesnej polszczyźnie. Większość $(66 \%)$ z tych osób do takich zmian zaliczyło zapożyczenia z języków obcych (w tym $34 \%$ mówiło o zapożyczeniach z języków obcych, $32 \%$ - o zapożyczeniach z języka angielskiego) ${ }^{4}$.

Według Krystyny Waszakowej różnorodne dziedziny życia, w których nastapiła ekspansja wyrazów obcych i tworzonych neologizmów, można podzielić na cztery ogólne kategorie zjawisk:

„1. Przeobrażenia ustrojowe, polityka w tym m.in. uwolnienie Polski spod wpływU ZSRR, przełamanie monopolu partii, zniesienie cenzury, tworzenie podstaw systemowych demokratycznego państwa, jego instytucji, form dzialania, dążenie Polski do uczestniczenia w strukturach europejskich, zwłaszcza w Unii Europejskiej - wyrażenia typu antytotalitaryzm, brukselizacja, euro deputowany, euro integracja, lobbista, postkomunista, uniokracja.

2. Ekonomia, finanse, nowe formy bankowości, tworzenie gospodarki rynkowej [...] - wyrażenia typu developer, fiskalizacja, leasing, monetaryzacja, refinansować.

3. Nowe zjawiska techniczne, a więc wszystko to co wiąże się z rozwojem cywilizacji i techniki, szczególnie informacji i komputeryzacji, telefonizacji, Internetu - wyrażenia typu billing, blog chip, cybernauta, e-biznes, e-mail, e-podpis, faks, hacker, infolinia, internauta, laptop, modem, monitoring, notebook, skaner, telebim.

4. Zdrowie, sport, styl życia, formy wypoczynku [...] - wyrażenia typu aerobik, bungee, cheesburger, dogoterapia, hipermarket, hydromasaż, jogging, lifting, peeling, skateboarding, survival"5.

Do wyżej wymienionych kategorii można dodać jeszcze terminy z dziedziny muzyki, gdzie wysteppuje stosunkowo dużo internacjonalizmów pochodzenia francuskiego, włoskiego, angielskiego. Dotyczy to zarówno nazw form muzycznych, nazw instrumentów, nazw tańców, jak i nazw stylów w muzyce rozrywkowej.

Ta sama autorka omówiła dwie zasadnicze grupy zapożyczeń: zapożyczenia leksykalne oraz zapożyczenia semantyczne (pominięto inne bardziej szczegółowe typy zapożyczeń, jako mniej istotne z punktu widzenia przedstawionych rozważań).

Zapożyczenia leksykalne (lub też właściwe) to wyrazy obce o różnym stopniu adaptacji w języku polskim, natomiast termin zapożyczenia semantyczne odnosi się do wyrazów, które pod obcym wpływem zmieniły swe dotychczasowe znaczenie.

\footnotetext{
${ }^{2}$ A. Fishman: The New English Order. „Foreign Policy” 1998/1999, no. 113 s. 26-40.

${ }^{3}$ M. Czarnecka: Łacina Internetu „Wprost” 1997, nr 20.

${ }^{4}$ P. Wróblewski: O możliwości przewidywania kierunku ewolucji języka polskiego. W: Przyszłość języka. Białystok 2001, s. 75-84.

${ }^{5} \mathrm{~K}$. Waszakowa: Przejawy internacjonalizacji w słowotwórstwie współczesnej polszczyzny. Warszawa 2005, s.12, s. 19.
} 
Włączanie do poszczególnych języków zapożyczeń o angielskim rodowodzie, zaadaptowanych już przez kilka języków, prowadzi do ich integracji, a raczej globalizacji językowej. Problemowi polskiej terminologii języków informacyjno-wyszukiwawczych, w tym problemowi zapożyczeń i internacjonalizmów w dobie globalizacji, obszerny artykuł poświęcił Wiesław Babik ${ }^{6}$, podkreślając, jak szczególne miejsce zajmują internacjonalizmy $w$ terminologii naukowej, technicznej i zawodowej.

„Międzynarodowa Organizacja Neologizmów Terminologicznych (obecnie Międzynarodowa Organizacja Terminologiczna - MOT), działająca na rzecz umiędzynarodowienia terminologii naukowej, technicznej i zawodowej, opublikowała w 1996 r. Multilingual Dictionary of International Terms zawierający internacjonalizmy z dziewięciu dziedzin w tym lingwistyki i informatyki".

\section{Języki haseł przedmiotowych wobec przemian w językach naturalnych}

Zjawisko wzmożonego napływu zapożyczeń i internacjonalizmów w polskim języku naturalnym, jakie obserwujemy w ostatnim dwudziestoleciu, nie pozostaje bez wpływu na kształtowanie systemów słowotwórczych tworzonych w Polsce języków haseł przedmiotowych. Każdy język haseł przedmiotowych jest ściśle powiązany $z$ konkretnym językiem naturalnym, ponieważ budowany jest w oparciu o słownictwo języka naturalnego, czerpane z różnego rodzaju żródeł: norm terminologicznych, słowników językowych, encyklopedii, opracowywanych dokumentów, a przy braku innych specjalistycznych źródeł, z Internetu. Tworzony w ten sposób zasób leksykalny o słownictwie paranaturalnym, (quasinaturalnym) - równokształtnym z wyrażeniami języka naturalnego - odzwierciedla wszystkie przemiany zachodzące w tym języku.

Problem zapożyczeń i internacjonalizmów, a także ich wpływ na wybór terminu preferowanego na hasło wzorcowe w językach haseł przedmiotowych, postanowiłam prześledzić na przykładzie uniwersalnych języków haseł przedmiotowych: jhp BN, jhp KABA oraz specjalistycznego Słownika haset przedmiotowych z dziedzin policyjno-prawnych (dalej: SHP) stosowanego w bibliotece Wyższej Szkoły Policji w Szczytnie. Hasła do ostatniego ze słowników tworzono w oparciu o język haseł przedmiotowych Biblioteki Narodowej. Założeniem autorów słownika było uściślenie haseł przedmiotowych z dziedzin policyjno-prawnych, a w szczególności policji, przestępczości, kryminalistyki, kryminologii, medycyny sądowej i prawa karnego. Słownik obejmuje również, w wybranym zakresie, hasła z dziedzin takich jak: psychologia, pedagogika, polityka, zarządzanie, filozofia, historia oraz pozostałe dziedziny prawa. Wybór tego słownika podyktowany był faktem, iż opracowanie zbiorów specjalistycznych wymaga znacznego uszczegóławiania haseł, co może stwarzać różne problemy terminologiczne. Hasła utrzymywane są w bazie kartoteki haseł wzorcowych w systemie ALEPH, obecnie baza liczy 26,5 tys. haseł.

Przy wyborze terminów na jednostki leksykalne języka haseł przedmiotowych istotne znaczenie ma wypracowanie ogólnych zasad/reguł, jakimi należy się kierować. Wspólną dla wszystkich tych języków zasadą jest zgodność z regułami języka polskiego, co potwierdzają cytowane materiały metodyczne.

${ }^{6}$ W. Babik: Polska terminologia języków informacyjno-wyszukiwawczych w dobie globalizacji. „Zagadnienia Informacji Naukowej” 2006, nr 1(87), s. 3-13. 
„W każdej sytuacji dąży się do tego, by redakcja językowa haseł wzorcowych zapewniała zachowanie podstawowych zasad języka polskiego.[...] Jest to szczególnie trudne gdy brakuje odpowiednich słowników specjalistycznych w języku polskim, zdarza się także, że brakuje odpowiednich terminów w słownikach. [...] Proces tworzenia leksyki KABA polega na znajdowaniu najwłaściwszej dla danego znaczenia formy językowej poprawnej w języku polskim"7.

„Współczesny język haseł przedmiotowych Biblioteki Narodowej stanowi kontynuację języka i metodyki opracowanej przez Adama Łysakowskiego" napisała Jadwiga Sadowska ${ }^{8}$. Na stronie internetowej Biblioteki Narodowej poświęconej jhp BN w rozdziale „Zasady doboru i redakcji merytorycznej haseł”, potwierdzono tę zasadę: „Autorki Słownika, Ewa Stępniakowa i Janina Trzcińska, podtrzymując podstawową zasadę metodyki Adama Łysakowskiego, tj. zasadę wyszczególniajacego formułowania tematów i uogólniającego formułowania określników, określiły zasady tworzenia JHP BN, które w większości są stosowane do dziś: słownictwo ma charakter uniwersalny, terminy służące jako tematy powinny odpowiadać polskiej terminologii z danej dziedziny i pochodzić z wiarygodnych polskich źródeł informacji. Początkowo jako źródła tematów preferowano najbardziej popularne, jednotomowe encyklopedie, wychodząc z założenia, że jest to źródło najbardziej dostępne dla przeciętnego użytkownika. Obecnie podstawowym zasobem terminów są wielkie encyklopedie uniwersalne oraz encyklopedie dziedzinowe i słowniki terminologiczne, w mniejszym stopniu monografie i artykuły naukowe, wydawnictwa urzędowe, akty prawne. Terminy są ponadto weryfikowane za pomocą aktualnego słownika języka polskiego" 9 .

Oprócz zasady zgodności z regułami języka polskiego, oba jhp przy redagowaniu haseł wzorcowych preferuja: rozpowszechnienie nazwy w piśmiennictwie, bazach danych, zasobach internetowych, poprawność językową, aktualne stosowanie, zwięzłość (pierwszeństwo ma forma krótsza pod warunkiem, że jest dostatecznie zrozumiała - jhp KABA), jednoznaczność, pochodzenie językowe (pierwszeństwo mają formy o polskim źródłosłowie).

Oba języki dopuszczają możliwość stosowania zapożyczeń w ściśle określonych warunkach. W przypadku jhp BN argumentacja jest następująca "hasła do opisu nowych zjawisk społecznych, nowych technologii, aktualnych wydarzeń politycznych zwykle nie sa jeszcze ujmowane i definiowane w publikacjach typu encyklopedycznego i słownikowego, stąd problem ze znalezieniem odpowiedniej, a nie całkiem potocznej nazwy. Hasła często bywają więc formułowane na podstawie innych dostępnych źródeł - zagranicznych baz danych, publicystyki, zasobów internetowych; czasem po utrwaleniu się bardziej właściwego nazewnictwa bywają zmieniane. Pewna grupa terminów, np. z zakresu nauk społecznych, ekonomicznych czy technicznych, które nie maja jeszcze polskiego odpowiednika jest wprowadzana w brzmieniu obcym, najczęściej angielskim (np.:Timesharing, Public relation, Hosting, Outsourcing, Streetworking)"10.

\footnotetext{
${ }^{7}$ Język haset przedmiotowych KABA. Zasady tworzenia stownictwa. Pod red. Teresy Głowackiej. Warszawa, 2000.

${ }^{8} \mathrm{~J}$. Sadowska: Język haseł przedmiotowych Biblioteki Narodowej. Poradnik. Warszawa 2001, s. 7.

${ }^{9}$ Biblioteka Narodowa. Język Haseł Przedmiotowych. [online]. [Dostęp 20.08.2010] <http://www.bn.org.pl/download/document/1280922227.pdf>.

${ }^{10}$ Ibidem.
} 
W przypadku języka KABA dopuszcza się, a nawet nakłada obowiązek, stosowania wyrażeń zapożyczonych z języków obcych w przypadkach, gdy nie maja one odpowiedników w języku polskim, np. Art Brut, Public relations, Streamer, lub gdy odpowiedniki te są mniej popularne i/lub używane w piśmiennictwie rzadziej od wyrażeń zapożyczonych np. Alergia zamiast Uczulenie (medycyna), Kosaćce zamiast Irysy.

Zwykle status hasła wzorcowego uzyskuje forma powszechnie używana. Wyrażenia nieprzyjęte za wzorcowe, ale brane pod uwagę przy redagowaniu formy hasła wzorcowego (w tym nazwy łacińskie), są wiązane z forma przyjętą (wzorcowa) relacją ekwiwalencji. W obu językach - jhp BN i jhp KABA - przyjęto zasadę zachowania naturalnego szyku wyrażenia preferowanego jako hasło wzorcowe tzn. szyku porzeczownikowego. Na pierwszym miejscu występuje rzeczownik, a po nim inne wyrażenia (przymiotniki, imiesłowy, liczebniki) określajace ten rzeczownik. W obu językach istnieją od tej zasady wyjątki dla stałych związków frazeologicznych np. Czarne dziury.

W przypadku SHP ogólne zasady wyboru formy hasła wzorcowego są takie same jak w jhp BN.

Na wybór terminu ( $w$ tym zapożyczenia) jako hasła wzorcowego ma również wpływ analiza zagranicznych słowników języków haseł przedmiotowych.

Wybór zapożyczenia jako hasła wzorcowego następuje w przypadkach, gdy:

a) polski odpowiednik zapożyczenia nie przyjął się w piśmiennictwie lub jest zbyt wieloznaczny, np.:

Reenginering - w języku KABA przyjęto jako hasło wzorcowe, umieszczając w relacji ekwiwalencji termin Reinżynieria;

Design - stosowany też w pisowni dizajn. W języku KABA przyjęty jako hasło wzorcowe, podobnie jak w językach LCSH i RAMEAU. Wprowadzono także termin Wzornictwo przemysłowe i w relacji ekwiwalencji do niego termin Design (przemysł). W słownictwie jhp BN przyjęto Wzornictwo przemysłowe, ale dla kategorii osób parających się tym zajęciem przyjęto hasło Designerzy;

Stalking - jhp BN, jhp KABA, SHP, przyjęły ten sam termin dla określenia pewnego typu zachowań przejawiających się nagabywaniem, osaczaniem, natrętnym uwielbianiem innych osób;

Dżihad - święta wojna islamska, w obu jhp BN i KABA przyjęte jako hasło wzorcowe;

World Wide Web - anglojęzyczne rozwinięcie skrótu WWW, tzW. Ogólnoświatowa Pajęczyna. To dosłowne polskie tłumaczenie nie przyjęło się: jhp KABA przyjął World Wide Web, jhp BN hasło Portal internetowy, SHP - Strony WWW. Jak wynika z tego przykładu, nie ma jednoznacznie przyjętego odpowiednika w języku polskim;

Talk show - internacjonalizm - przyjęty jako hasło wzorcowe w językach: LCSH, RAMEAU, jhp BN, jhp KABA;

Animaloterapia - termin przyjęty jako hasło wzorcowe w jhp BN - w leksyce jhp KABA nie ma takiego terminu;

Jogging -internacjonalizm, przyjęty w LCSH, RAMEAU i jhp KABA, w leksyce jhp BN nie ma takiego terminu;

Alibi - termin przyjęty w jhp BN, nie występuje w słownictwie KABA; 
Curriculum vitae - termin przyjęty w jhp KABA i RAMEAU jako hasło wzorcowe (w jhp KABA na podstawie Nowy Leksykon PWN Warszawa, 1998); w jhp BN występuje jako termin ekwiwalentny do hasła Biografie, w SHP jako termin ekwiwalentny do hasła Życiorysy urzędowe;

Biznesplan - termin przyjęty jako hasło wzorcowe w leksyce KABA (na podstawie Słownika Współczesnego Języka Polskiego); w jhp BN i SHP jest terminem ekwiwalentnym do hasła przedmiotowego rozwiniętego Przedsiębiorstwo - planowanie;

Casting - termin przyjęty w jhp BN jako hasło wzorcowe, w jhp KABA termin ekwiwalentny do hasła przedmiotowego rozwiniętego Kino - obsada;

Leasing - termin przyjęty w jhp KABA, jhp BN i SHP;

Outsourcing - termin przyjęty w jhp KABA, jhp BN i SHP.

b) w polskiej rzeczywistości nie występuje zjawisko, dla którego wprowadzono termin, np.:

Fabliaux - przyjęty w tej samej formie co w RAMEAU również w językach LCSH i KABA, gatunek $w$ literaturze francuskiej XII-XIV. W słownictwie BN i SHP nie ma takiego terminu;

Kasyda - gatunek literatury arabskiej, termin przyjęty zarówno w jhp BN jak i w jhp KABA;

Ramadan - miesiąc z kalendarza muzułmańskiego, przyjęty zarówno w jhp BN jak i w jhp KABA;

Commentaire compose (dysertacja) - rodzaj komentarza w pracy naukowej francuskiej, przyjęty w jhp KABA w formie zaproponowanej przez RAMEAU. W słownictwie BN i SHP nie ma takiego terminu;

Sumo - zapasy japońskie, termin przyjęty zarówno w jhp BN jak i w jhp KABA;

Sushi - potrawa japońska, termin przyjęty zarówno w jhp BN jak i w jhp KABA;

Judo - japońska sztuka walki, termin przyjęty w jhp KABA, w jhp BN i SHP również termin przyjęty ale w wersji spolszczonej Dżudo.

Jednym z najważniejszych problemów przy opracowywaniu słownictwa języków haseł przedmiotowych jest ustalanie ekwiwalentów terminów wybranych na hasło wzorcowe.

Jeśli termin zapożyczony nie został wybrany jako hasło wzorcowe pełni funkcję terminu ekwiwalentnego np.:

Souvenirs - przyjęty w RAMEAU i LCSH, w języku KABA jest ekwiwalentem hasła Pamiątki (przedmioty). W słownictwie jhp BN nie ma takiego terminu;

Product placement - $w$ języku KABA termin ekwiwalentny do hasła wzorcowego Lokowanie produktu (polski termin został uznany za przyjęty w piśmiennictwie na podstawie dostępnych źródeł), w jhp BN Product placement jest hasłem wzorcowym a Lokowanie produktu terminem ekwiwalentnym;

Bodyguard - w języku KABA termin ekwiwalentny do hasła wzorcowego Agenci ochrony osobistej, w jhp BN i w SHP przyjęto jako hasło wzorcowe Pracownicy ochrony mienia i osób;

Bilingwizm - w obu językach jhp KABA i jhp BN termin ekwiwalentny do hasła wzorcowego Dwujęzyczność;

Puzzle - w jhp BN jest terminem ekwiwalentnym do hasła wzorcowego Układanki, w jhp KABA termin przyjęty tak jak w LCSH i RAMEAU; 
Gender roles - w jhp KABA termin ekwiwalentny do hasła Rola wynikająca z płci (Encyklopedia psychologii, Warszawa, 1998). W jhp BN nie ma takiego terminu.

e-[przedmiot] w jhp BN, jhp KABA, SHP

\begin{tabular}{|c|c|c|c|}
\hline e-[przedmiot] & JHP KABA & JHP BN & SHP \\
\hline e-bank & & Bank internetowy & \\
\hline e-biznes & Handel elektroniczny & $\begin{array}{l}\text { Gospodarka } \\
\text { elektroniczna }\end{array}$ & \\
\hline e-book & Książki elektroniczne & Książki elektroniczne & \\
\hline e-czasopisma & & $\begin{array}{l}\text { Czasopisma } \\
\text { elektroniczne }\end{array}$ & \\
\hline e-duszpasterstwo & $\begin{array}{c}\text { Internet } \\
\text { w duszpasterstwie }\end{array}$ & & \\
\hline e-edukacja & Internet w edukacji & & \\
\hline e-firma & & $\begin{array}{c}\text { Przedsiębiorstwo } \\
\text { internetowe }\end{array}$ & \\
\hline e-gospodarka & & $\begin{array}{l}\text { Gospodarka } \\
\text { elektroniczna }\end{array}$ & \\
\hline e-government & $\begin{array}{c}\text { Elektroniczna } \\
\text { administracja publiczna }\end{array}$ & & \\
\hline e-hazard & $\begin{array}{l}\text { Gry hazardowe } \\
\text { w Internecie }\end{array}$ & & \\
\hline e-kontrakty & & Umowy elektroniczne & Umowy elektroniczne \\
\hline e-księgarnie & & $\begin{array}{l}\text { Księgarstwo } \\
\text { internetowe }\end{array}$ & \\
\hline e-learning & $\begin{array}{l}\text { Internet w edukacji, } \\
\text { Kształcenie online }\end{array}$ & Nauczanie na odległość & Nauczanie na odleglość \\
\hline e-mail & Poczta elektroniczna & Poczta elektroniczna & Poczta elektroniczna \\
\hline e-mail art & Sztuka Internetu & & \\
\hline e-marketing & $\begin{array}{c}\text { Marketing } \\
\text { w Internecie }\end{array}$ & Marketing elektroniczny & \\
\hline e-muzea & & Muzea wirtualne & \\
\hline e-papierosy & Papierosy elektroniczne & Papieros elektroniczny & \\
\hline e-pieniądze & & Pieniądz elektroniczny & \\
\hline e-podpis & Podpis elektroniczny & Podpis elektroniczny & Podpis elektroniczny \\
\hline e-pornografia & Pornografia internetowa & & \\
\hline e-przedsiębiorstwo & & $\begin{array}{l}\text { Przedsiębiorstwo } \\
\text { internetowe }\end{array}$ & \\
\hline e-śmieci & Odpady elektroniczne & & \\
\hline e-terapia & Internet w psychoterapii & & \\
\hline e-umowy & Umowy elektroniczne & Umowy elektroniczne & Umowy elektroniczne \\
\hline e-urząd & & $\begin{array}{l}\text { Administracja } \\
\text { elektroniczna }\end{array}$ & \\
\hline e-usługi & Usługi sieciowe & Usługi elektroniczne & \\
\hline
\end{tabular}

Brak jakiegoś terminu z podanych wyżej przykładów w słownictwie omawianych języków nie oznacza jego eliminacji, najczęściej nie zostały jeszcze opracowane $z$ powodu braku dokumentów na dany temat $w$ bibliotece lub tak jak w 
przypadku SHP dobór terminów ogranicza zakres tematyczny. Szczególnym problemem przy opracowywaniu słownictwa jhp jest ekspansja w języku naturalnym wyrazów z pierwszym członem -e, wzorowanych na międzynarodowym skrócie e-mail, w którym przymiotnik electronic zredukowano do elementu -e. Element -e występuje zarówno w zapożyczeniach, jak i strukturach tworzonych na gruncie rodzimym, a jego znaczenie rozszerzono na 'internetowy, wirtualny, związany z siecią elektroniczna'. Wszechobecny w słownictwie naturalnym, stanowi coraz większy problem również w językach haseł przedmiotowych. Generalnie $w$ językach haseł przedmiotowych wyrazom $z$ e- elementem wyznaczono funkcję terminu odrzuconego, zarówno w jhp BN jak i w językach KABA i SHP. Poniżej w tabeli podano przykłady złożeń z członem -e często spotykane w języku naturalnym wraz z ich odpowiednikami w wyżej wymienionych językach haseł przedmiotowych.

Poniżej złożenia z członem e- spotykane w źródłach, dla których nie znaleziono ekwiwalentów w żadnym z wymienionych jhp:

e-archiwum, e-autor, e-banking, e-bankowość, e-bay, e-biblioteka, e-bilet, e-biuletyn, e-biznesmen, e-czytanie, e-demokracja, e-dokument, e-donos, e-dyktando, e-ekonomia, e-film, e-gazeta, e-giełda, e-handel, e-kasyno, e-klient, e-konsumpcja, e-konto, e-literatura, e-nauka, e-notatki, e-państwo, e-papier, e-PIT-37, e-powieść, e-praca, e-przyszłość, e-publikacje, e-rada, e-rynek, e-sklep, e-spółka, e-sprawozdanie, e-student, e-studia, e-superkonto, e-szkoła, e-świat, e-teksty, e-wybory, e-wykluczenie, e-zakupy, e-zbiory, e-złodzieje.

Wyznaczenie e-złożeniom funkcji terminu ekwiwalentnego łączy się z akceptacją pojawienia się $w$ jednym miejscu $w$ indeksie wciąż rosnącego zbioru terminów z przedrostkiem e-.

Podobne problemy sprawia napływ do języka polskiego konstrukcji z euro(szczególnie w dziedzinach ekonomii, bankowości, finansów, gospodarki, polityki, handlu, sportu). Konstrukcje zawierające euro- to głównie zapożyczenia (najczęściej z języka angielskiego) np. euroczek lub „hybrydy” zawierające internacjonaine euro- i element rodzimy np. eurourzędnik.

Słowniki języków haseł przedmiotowych są systemami otwartymi i muszą być stale modyfikowane. W przypadku wprowadzania nowych haseł wzorcowych (szczególnie zapożyczeń) istnieje konieczność dokonania zmian w relacjach z hasłami już istniejącymi. Poprawne „ulokowanie” zapożyczenia w leksyce jhp sprawia więcej trudności niż termin od dawna istniejący w języku naturalnym.

W praktyce większość jiw pełni dwie funkcje równocześnie: języka informacyjnego, służącego do charakteryzowania dokumentów oraz języka wyszukiwawczego, stosowanego do określania potrzeb informacyjnych użytkowników systemu. Realizacja funkcji języka informacyjnego ma wpływ na jego funkcję wyszukiwawcza i chociaż funkcja wyszukiwawcza jest brana pod uwagę przy tworzeniu języka, to w przypadku zapożyczeń dążenia twórców języka i oczekiwania jego użytkowników moga być rozbieżne, a przyjęta w jhp zasada zgodności z regułami języka polskiego i źródłosłowu polskiego może być przez użytkowników ignorowana na rzecz preferowanych modnych zapożyczeń z innych języków. Większość użytkowników chciałaby znaleźć informację, posługując się pytaniem sformułowanym intuicyjnie, zaś ich ocena jhp często dokonywana jest przez pryzmat jednoznaczności wszystkich wyrażeń, łatwości nauczenia się i posługiwania się tym językiem. 
Przenikanie się kultur i języków jest zjawiskiem naturalnym. We Francji rząd wspiera walkę z anglicyzmami, tworząc np. francuską nomenklaturę komputerową. Nie obawia się znacznego napływu zapożyczeń język rosyjski, przyjmując tylko terminologię związaną z funkcjonowaniem sprzętu i oprogramowania oraz pisząc cyrylicą obce wyrazy. Skoro „uchwalono ustawę dotyczącą ochrony języka ojczystego (rosyjskiego) nie trzeba niepokoić się napływem angielskiej terminologii"11. W Polsce w 1999 roku Sejm uznał język polski za dobro narodowe i uchwalił Ustawę o języku polskim ${ }^{12}$. O czystość polszczyzny ma dbać jako instytucja opiniodawczo-doradcza Rada Języka Polskiego, ale jej rola jest ograniczona.

Na temat spolszczania terminów z zakresu informatyki wypowiadał się Stanisław Lem, traktując humorystycznie próbę spolszczenia wyrazu interfejs na „międzymordzie” i pisząc: „skoro Internet niezbyt przeze mnie lubiany tak się zadomawia, to angielskiego trzeba się uczyć, albowiem języki etnicznie lokalne tworzą silnie erodowane agresją angielską wysepki. Ja więc spolszczać na siłę nie zamierzam"13.

Intensywne przejmowanie zapożyczeń, „umiędzynaradawianie” słownictwa dzisiejszej polszczyzny, a zatem również słownictwa jhp wynika z potrzeby jej wzbogacania w związku ze zmianami rzeczywistości. Chociaż wśród najnowszych zapożyczeń leksykalnych dominują anglicyzmy, nie znaczy to bynajmniej, że zupełnie nie ma wyrazów pochodzących z innych języków: z francuskiego, włoskiego, hiszpańskiego, japońskiego, rosyjskiego, arabskiego. W procesie globalizacji politycznej, gospodarczej, ekonomicznej dochodzi do zacieśniania kontaktów między państwami, narodami, w tym także kontaktów językowych, co przejawia się powiększeniem obszaru internacjonalizmów w poszczególnych językach i procesem unifikacji języków. Zjawisko przenikania wyrazów obcych do języka polskiego budzi mieszane uczucia - od tolerancji, po obawy o zachowanie tożsamości narodowej, kulturowej i językowej. Twórcy języków haseł przedmiotowych są wnikliwymi obserwatorami zmian w języku naturalnym podejmując decyzje mające wpływ na wybór terminów użytych jako hasło wzorcowe.

\section{Bibliografia}

1. Babik W.: Termin i jego status w systemie leksykalnym języka informacyjno-wyszukiwawczego. „Zagadnienia Informacji Naukowej” '1999, nr 1(73), s. 13-14.

2. Babik W.: Polska terminologia języków informacyjno-wyszukiwawczych $w$ dobie globalizacji. „Zagadnienia Informacji Naukowej” 2006, nr 1(87), s. 3-13.

3. Chmiolek M.: Stownik haseł przedmiotowych z dziedzin policyjno-prawnych stosowanych w bibliotece Wyższej Szkoły Policji w Szczytnie. Szczytno, 2008.

4. Encyklopedia językoznawstwa ogólnego. Wrocław, Warszawa, Kraków, 1993.

5. Język haseł przedmiotowych KABA. Zasady tworzenia słownictwa. Pod red. T. Głowackiej. Warszawa, 2000.

6. Kurek-Kokocińska S.: Związki języka naturalnego i języków informacyjno-wyszukiwawczych - na przykładzie języka haseł przedmiotowych. "Zagadnienia Informacji Naukowej” 2004(83), s. 46-65.

7. Przyszłość języka. Pod red. S. Krzemień-Ojak, B. Nowowiejskiego. Białystok, 2001.

${ }^{11} \mathrm{G}$. Trifomova: Anglojazychye zaimstvovanija russkij jazyk pererabatyvaet, ustaivajet i kodificiruet. „Ex Libris” 2004, nr 28, s. 5-6.

${ }^{12}$ Dz. U. z 1999 r. Nr 90, poz. 999.

${ }^{13}$ St. Lem: Bomba megabitowa. Kraków 1999, s. 55. 
8. Sadowska J.: Język haset przedmiotowych Biblioteki Narodowej. Poradnik. Warszawa, 2001.

9. Waszakowa K.: Przejawy internacjonalizacji w słowotwórstwie współczesnej polszczyzny. Warszawa, 2005.

\section{Summary}

The article discusses how the phenomenon of increased inflow of borrowings in natural language being observed within last twenty years influences formative system of subject headings languages. Internationalisation and effect of globalization are mentioned as a trend indicating the direction of changes in natural and subject heading languages. 